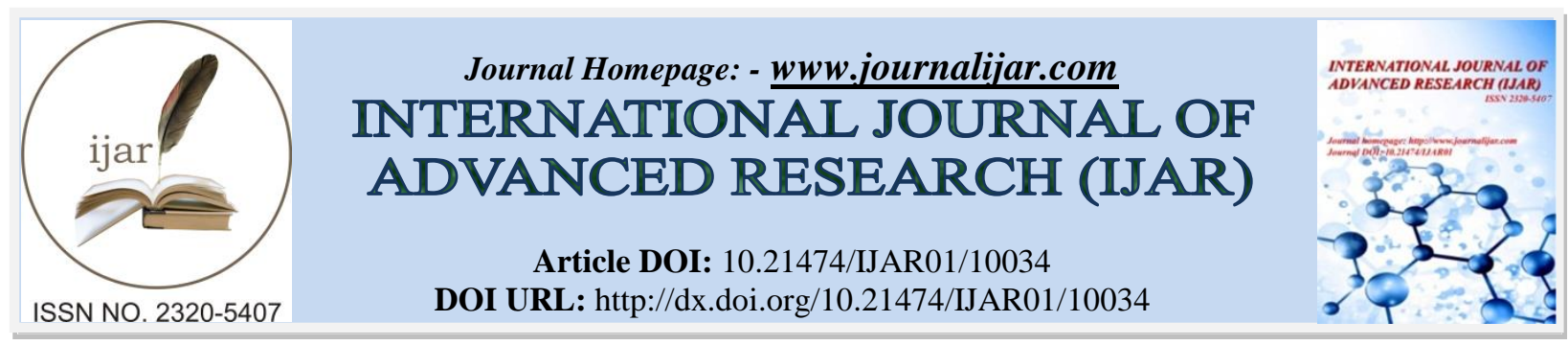

RESEARCH ARTICLE

\title{
MANAGEMENT AND OUTCOME IN MAJOR HEAD AND NECK ELECTRICAL BURNS
}

\section{S.Ganga Bhavani and Dr.N.Naga Prasad.}

1. Assisstant professor department of plastic surgery guntur medical college guntur.

2. Prof \&Hod Osmania Medical College Hyderabad.

\section{Manuscript Info}

Manuscript History

Received: 10 September 2019

Final Accepted: 12 October 2019

Published: November 2019
Abstract

\section{Introduction:-}

Electricity is now an indispensable part of civilization. In the modern times the use of electricity has increased many times and so has the incidence of high/low voltage electrical burn injuries. The incidence of high voltage electrical injuries is much higher in developing countries when compared to developed countries. Electrical burns are the most devastating of all thermal injuries. spectrum of electrical injuries is complex due to extensive tissue loss and damage to essential structures of the involved areas often requiring extensive plastic-reconstructive procedures. Electrocution can occur while working or illegal handling of the lines. Electrical injuries account for 3-5\% of all admissions to major burn centers. In US one person dies per day due to electrical injuries at his work place, 0.8-1\% accidental deaths are caused by electricity and 13 days of work lost per electrical injury ${ }^{5}$. No such detailed data is available from Europe, Asia, Africa or Indian subcontinent. ${ }^{5}$ Injuries caused by electricity can be of three types;(a) direct contact burn, (b) flash burn or (c) burn froman electric arc.

Materials and methods: This is a prospective study conducted at Osmania General Hospital Hyderabad from September 2013 to september 2015. 91 patients were admitted with electrical burns out of them 64 had head and neck involvement out of the 64 patients, 32 of them had major electrical burns of head and neck and were included in the study. Major electrical burns are those electrical burns which resulted in patients death, prolonged hospital stay, flap covers

On arrival at the emergency department the patients were evaluated for vitals and resuscitated using strict ALTS protocols. Complete history regarding the occupation, mode of injury, duration of contact, voltage, h/o of fall from height, any associated injuries ,co morbidities is recorded. The percentage of burns was calculated by Wallace rule of nines. The fluid replacement was done with normal saline and titrated to maintain the urine output of 0.5 to $1 \mathrm{ml} / \mathrm{kg} / \mathrm{hr}$. Myoglobinuria when present was treated with mannitol and sodium bicarbonate. . Patients with h/o fall from height were examined for any head injury, long bone fractures,blunt trauma abdomen of chest and then treated accordingly by the concerned specialist. Psychiatric counselling was advised to overcome stress and depression. Electrical burn wound was managed by serial surgical wound debridements followed by resurfacing of the defects with skin grafting and/or loco-regional flap covers as indicated. Associated burns over the limbs were treated by Fasciotomy and amputations when indicated. The coverage of the wounds was delayed because of the high chances of progressive necrosis of the injured tissue due to progressive microthrombus formation. Detailed analysis of these 32 cases with major head and neck electrical burns was performed in terms of the following variables

1. Incidence 
2. Age .

3. Sex .

4. Occupation

5. Mode of Electrical Burns (Domestic,Workplace,Accidental.)

6. Percentage of burns

7. Sites Of Involvement

8. Voltage.

9. Associated Injuries.

10. Procedures Done.

11. Complications.

12. Mortality.

\section{Results:-}

Incidence

\begin{tabular}{|l|l|l|}
\hline Total no of burns admitted between 2013-2015 & 1980 & Percentage \\
\hline Total no of electrical burns & 91 & $4.59 \%$ \\
\hline No head and neck burns & 64 & $70 \%$ of EB and \\
\hline Major head and neck electrical burns & 32 & $35 \%$ Of the total no:of EB \\
\hline
\end{tabular}

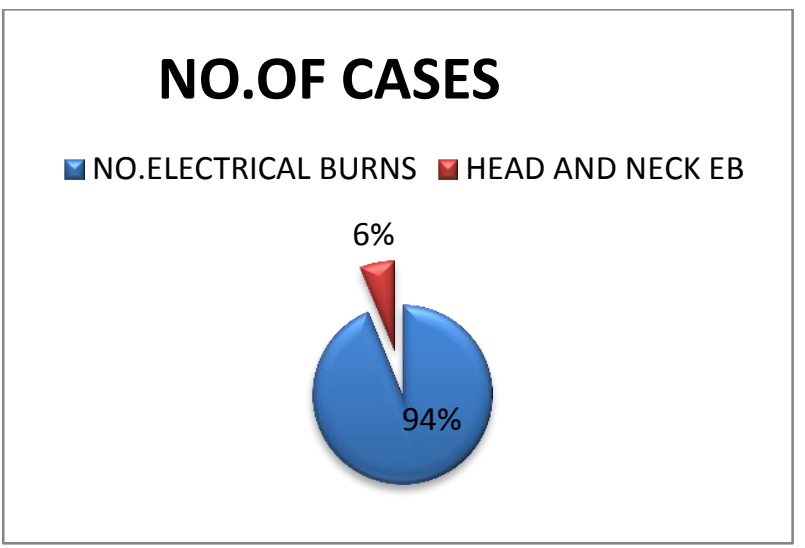

\section{Sex distribution:}

In this study males (31pts-96\%) were more commonly affected and only one was a female $(4 \%)$.

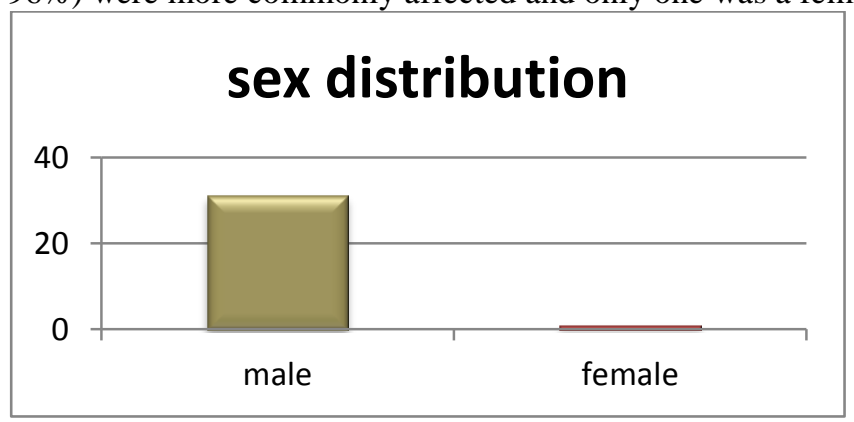

Age distrbution:

The age of the patients in this study range from 4 yrs to 56 yrs .the most commonly affected were in between 20$30 \mathrm{yrs}$. $(53 \%)$ followed by 11 to 20 yrs.

\begin{tabular}{|l|l|l|}
\hline Age (years & Number of patients & Percentage \\
\hline $0-10$ & 3 & $9 \%$ \\
\hline $11-20$ & 5 & $16 \%$ \\
\hline $20-30$ & 17 & $53 \%$ \\
\hline $30-40$ & 4 & $13 \%$ \\
\hline $40-50$ & 1 & $3 \%$ \\
\hline
\end{tabular}




\begin{tabular}{|l|l|l|}
\hline$>50$ & 2 & $6 \%$ \\
\hline
\end{tabular}

\section{Occupation:}

The most commonly affected occupational group were the elecrtical workers,followed by farmers and the construction labourers.

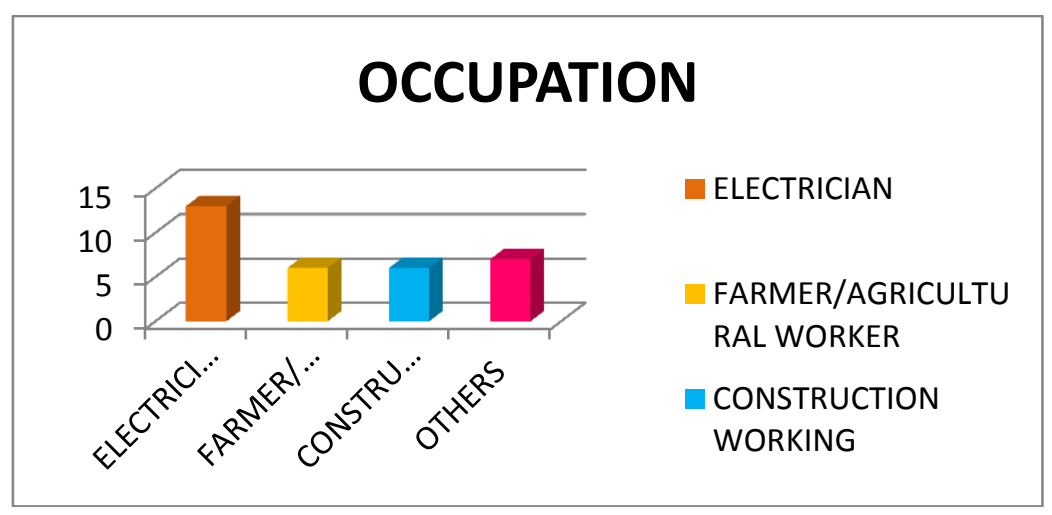

\section{Mode /cause of the burns:}

Most of the burns were due to accidental contact with the live wires while working,playing,etc.work related injuries were seen in 25 cases(78.12\%). In children the common cause was accidental contact with live high voltage wire while flying kites.In the farmer /agricultural worker group the burns occurred while operating the irrigation pump sets/illegal handling of the high voltage wire.

\section{Voltage :}

Most of the burns(87.5\%) were due to high voltage current where as only 4 cases (12\%)were due to low voltage domestic current.

\section{Percentage of burns:}

Most the burns were between 20-30 percent.

\begin{tabular}{|l|l|l|}
\hline$\%$ OF BURNS & NO:PTS & PERCENTAGE \\
\hline$<10 \%$ & 2 & $6 \%$ \\
\hline $11-20 \%$ & 7 & $22 \%$ \\
\hline $20-30 \%$ & 14 & $44 \%$ \\
\hline $30-40 \%$ & 5 & $16 \%$ \\
\hline $40-50 \%$ & 2 & $6 \%$ \\
\hline $50-60 \%$ & 1 & $3 \%$ \\
\hline $60-70 \%$ & 1 & $3 \%$ \\
\hline
\end{tabular}

\section{Sites of involvement.:}

Head And Neck Is Divided Into The Following Units

1. Scalp,

2. Forehead

3. Periorbital region

4. Nose

5. Lips

6. Cheeks

7. Neck 


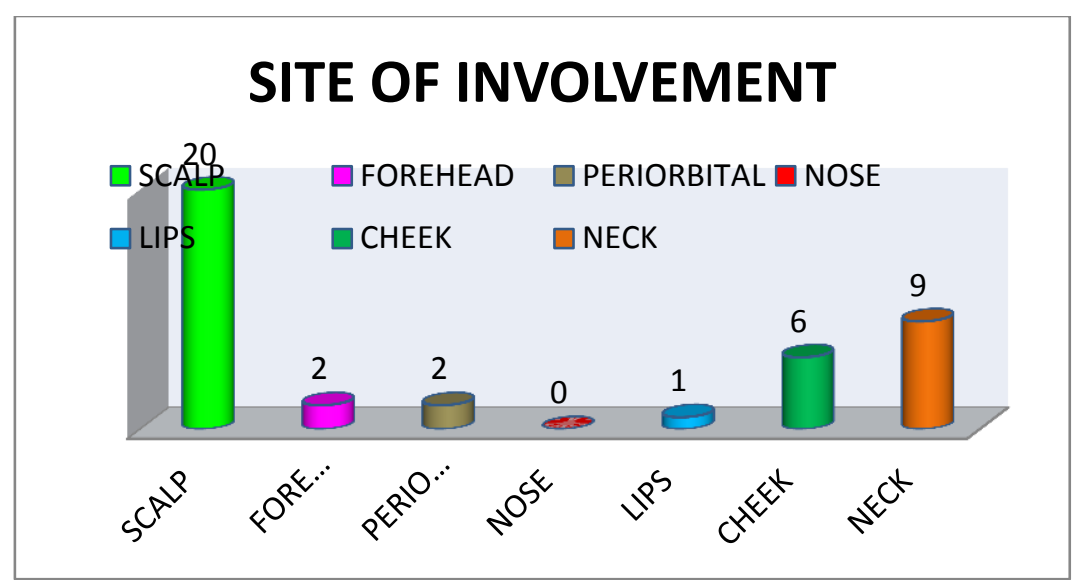

\begin{tabular}{|l|l|l|}
\hline Sl.no & Site of involvement & No.of pts \\
\hline 1 & Scalp & 20 \\
\hline 2 & forehead & 2 \\
\hline 3 & Periorbital region & 2 \\
\hline 4 & nose & 0 \\
\hline 5 & lips & 1 \\
\hline 6 & Face(cheeks,mandibular region) & 6 \\
\hline 7 & neck & 9 \\
\hline
\end{tabular}

\section{Procedures done:}

most common procedure pertaining to the head and neck burns was the debridement and transposition flap cover.one was treated by tissue expansion followed by flap cover.other procedurs are decortication followed by ssg.pmmc flap was done in two cases .debridement was done for every case.

1. flap covers

2. $\operatorname{ssg}$

3. primary closures

4. tissue expansion

\section{Mortality:}

Out of the 32 cases seven patients expired.Four of them had deep burns over the vital areas with exposed vitalsprecordium,brain,great vessels of the neck.A $12 \mathrm{yr}$ old child expired because of the severe cardiac dysrrhythmias within $48 \mathrm{hrs}$ of admission

\section{MORTALITY TOTAL NO. OF CASES--...}

$31 \%$

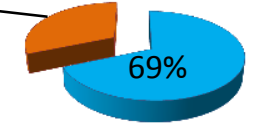

\section{Discussion:-}

In our study out of the total 1980 burn patients during sep 2013 to sep 2015, 91(4.59\%) patients had electrical injury.out of the 91 electrical burn injuries 64(70\%) had head and neck involvement and 32(50\%) of them had major burns.. Among the patients studied the electrical injuries were mostly work related which include the electricians(13),the farmers(6), the construction workers(6), constituting upto 25(78\%)of the victims. In Kasana et al 
study the work related injuries were seen in $75.93 \%$ of patients. In Jain et al study the work related injuries were $65.3 \%$.

The various types of electrical burns were accidental in nature and none of them were homicidal or suicidal. most of them are occupation related and were due to lack of proper training and non-adherence to safety norms .hence they are preventable by proper training strict implementation of the safety norms. and second most common mode is accidental contact with the live wires which hanging without proper insulation in the residential areas and in the fields. All the tension lines must be insulated in the rural and residential areas and the electrical department workers need to be properly trained and enforcement of strict laws should be done to prevent electrical burn injuries. Proper training of electric department worker can prevent such accidents in future. Up-gradation of transmission lines especially in rural areas is equally important to reduce the incidence of such injuries. The other measures include proper communication between the workers repairing lines and grid station, high quality transmission lines and poles, periodic maintenance and strict implementation of safety norms.

\section{References:-}

1. Who http://www.who.int/mediacentre/factsheets/fs365/en

2. Electrical and lightning injuries mary ann cooper timothy g. Price Electric burns injuries of head and neck region: a retrospective study

3. Sameer jain,s c sharma1,s p sinha2,s k jain3 international journal of scientific study,jan 2014,vol-1,issue 4

4. A review of 5 years experience in management of electrical injuries--smitha s. Segu, vijay jaganathan, amaresh v. Biradar, shankarappa mudukappa -Indian journal of burns dec 2014 vol 22, issue 1

5. The management of electrical burns--by i. F. K. Muir, M.B.E., M.B., F.R.C.S.-the postgraduate medical journal ., may 1957

6. Involvement of head and neck region in high voltage injuries :a study from the himalayan valley --reyaz ahmed kanasa et al-indian journal of burns-dec-2013,vol-21,issue 1

7. Clinicoetiological profile and outcome of electrical burns at rljh , a tertiary centre of south india, ambikavathy mohan1, kumar srinivasan2, bhaskaran ashokan3

8. Total burn care-Herndon $-3^{\text {rd }}$ edition

9. Haberal ma. An eleven-year survey of electrical burn injuries. J burn care Rehabil. 1995;16:43-8.

10. Babik j, sandor, sopko. Electrical burn injuries. Annals of burns and fire disasters, vol. Xi, n. 3, september 1998. 